\title{
School-Community Partnership Mitigates Student Truancy: The Case of a Seaman's Son in Ghana
}

\author{
Dr. Anthony Kudjo Donkor \\ University for Development Studies \\ Faculty of Education, Tamale - Ghana
}

\begin{abstract}
The author revisited the school site where a case study on parental involvement on their children's education was held five years ago. This move was in response to a participant's request during the research interview five years ago. The participant requested that the research findings of the study should not be left on the shelf to collect dust. The author therefore made a follow-up study to find out the impact of the previous study, including recommendations of the study on the students, institution and community. Participants' contributions in the previous study were reviewed by the author. These include perceptions of parents of children in the school where the study took place, perceptions of community leaders, perceptions of teachers and the perceptions of school administrators on education. The follow-up study discussed a success story centered round a student, who played truancy and later became a hero. The outcome of the study confirmed the benefits derived from teamwork by parents, teachers, school administrators, community members as well as community leaders in educating a child. In addition, it laid bare the defects on children whose parents were not involved in their education. This study will be of great importance to teachers, parents, educational leaders, community leaders and community members in children's education.
\end{abstract}

Keywords: Parents, teachers, school administrators, community members, community leaders.

\section{INTRODUCTION}

A school system draws its major strengths and weaknesses from the attitudes of the community it serves. The quality of a school program may depend largely on public understanding of the school's mission. Cooperation is fundamental to living in a social system. The responsibility for learning is a shared responsibility requiring commitment from the student, the teacher, the family, and the community (Arlington heights school district 25, 1999). In addition, community participation in the affairs of the school is essential if the school system and the community are to maintain mutual confidence and respect, and work together to improve the quality of education for students. The public has many resources and experiences which may be useful to the school. It is obvious that both school and community need each other's service to thrive in this contemporary era, since they play a complimentary role in the lives of people.

On the other hand, (Swap, 1993; Epstein, 1995, as cited in Lazar \& Slostad, 1999) assert that "Teachers, parents, and administrators have generally received limited information about how to work together effectively...most educators enter schools without an understanding of family background, concepts of caring, or the frame work of partnership...most teachers and administrators are not prepared to understand, design, implement, and evaluate practices of partnerships with the families of their student" (21 \& 26). 
According to Charlton (1983), Administrators who have a community-oriented philosophy are more likely to have positive school-community relations. He reiterated that every school should have three types of information about the community it serves. Information about the composition of the community, such as the income, educational level and occupations of the majority of the residents would be useful in formulating new programs or adapting existing ones to meet students' needs. In addition, knowledge about the community's opinion about broad educational issues and the day to day operation of the school is also important. Moreover, a school's familiarity with the educational resources available in the community that can be utilized to enrich and enhance the school program is very imperative. Partnerships between schools and other community organizations form a strong base for experiential learning and offer students opportunities to make connections that will be relevant to their future careers. Partnerships also allow staff members and students to work with professionals from a variety of fields (Tunseth and Nowicki, 2003). Furthermore, when students work with the community, local organizations and individuals gain a greater understanding of the school and its needs and strengths. People outside the school gain positive impressions of students and their capabilities, which strengthen the community as a whole.

Dei (2004) advocates that schools must bring adults into the school to actively collaborate as partners interested in the development of educational programs. He states that seeing parents as teachers and guides also breaks down the walls separating schools from their local communities. He claimed that community participation is essential for ensuring that local cultures are reclaimed and used as knowledge resources in the process of education. Within a locality, schools need to be linked to social and cultural life of the communities. A strong partnership between schools and the local community can be forged by reporting on the progress of programs to locally elected bodies, advisory working groups and through workshops and symposiums Strategies for greater participation in the school activities and programs would be developed under the direction of school administrators and educators but in close consultation with an advisory or elected community body (Dei, 2004).

\section{LITERATURE REVIEW}

It is obvious that when drop-out rates and repetition rates are high, educators look to the schools to investigate the causes within the school system for those failures and in doing so they largely ignore the home environment, including most importantly the parents. However, the environment has by far the greatest influence on a child's ability and desire to attend school, to progress at the appropriate rate and to use the knowledge acquired in the classroom to best advantage (Booth, 1997). When creating the highest-quality instructional environment is a shared goal, parents transform from passive supporters to active members of the educational community. When children see the support, excitement about learning, and teamwork between home and school, they too become excited. They sense the value in learning, and their intrinsic motivation for learning grows (McLoughlin et al., 2003).

Research shows positive results in student achievement, attendance, health, and discipline when parents are partners in their children's education; and to build this partnership requires the three-pronged approach: families connecting to schools; schools connecting to families; and communities connecting to both schools and families (Boal, 2004). Inviting parents, members of the business community, and service organizations to identify academic goals and standards and quantify measures of progress "sends the message that what students learn and how well they learn it isn't an issue just for teachers and administrators but is a real priority for the community as well" (Wright and Saks, 2000, as cited in Cunningham, 2004). Trotman 
(2001) states that whether it is a routine task or a task that seems to be insurmountable, collaboration among parents, teachers, and other school personnel promises positive outcomes. Where there is empowerment, there is positive student and parent response as well as improvement in motivation and self-confidence. She asserts that teachers' attitudes as well as a hostile insensitive school environment also contribute to the amount of parent involvement that takes place within the classroom and school building. Teachers who hold expectations or believe that parents do not care about their children and do not want to be involved in their education may lead to a self-fulfilling prophecy and directly contribute to the lack of parental involvement and to student failure. Interacting with parents extends the school's capacity to understand and appreciate the values and culture of the families and to meet the educational needs of the children they serve more effectively (Winters, 1993, as cited in Trotman, 2001).

According to (Epstein and Salinas, 2004), a school learning community includes educators, students, parents, and community partners who work together to improve the school and enhance students' learning opportunities. The home, school, and community connections make school subjects more meaningful for students. In addition, to learn at high levels, all students need the guidance and support of their teachers, families, and others in the community.

For students to perform to the best of their ability both academically and behaviorally, they must be in school on a consistent basis and receive support from their parents and guardians. Consistent parental involvement is a key to achieving this goal (Trotman, 2001). The role of guide is, in many ways, tied to parents' ability to understand the value of education, to understand how the system works, what is expected of them in terms of helping with homework, paying fees for extra tutoring, purchasing textbooks and how to effectively advocate on behalf of their children. Being an educator enables one monitor, guide and teach one's children (Dei, 2004). In parents' role as guides, parents often navigate between their children's desires, interests and choices and what they as parents perceive to be in their children's best interest. Astone \& McLanahan (1991), assert that ineffective or inadequate parental assistance may lead a child to feel overwhelmed and consequently to withdraw from school. They claim that helpful participation in a child's school career requires not only that parents hold high aspirations, but that they transmit their aspirations to their children. If children do not feel close to their parents, or if parents are not available to supervise their children, parental influence may be seriously undermined.

Recently, ethnographers have been concerned with children who, against the odds, manage to break the intergenerational cycle of poverty. Their evidence indicates that success in school among poor children of all family types is related to deliberate efforts on the part of parents to inculcate discipline and good study habits in their children (Clarke, 1983, as cited in Astone \& McLanahan, 1991). It is established that parental practices are related to all of the school achievement indicators, including grades, attendance, attitudes, expectations, school retention, and degree completion. Research has found that changes in family structure are associated with declines in the quality of parental involvement. The notion of a community (DuFour \& Eaker, 1998), as it relates to alignment of common purposes among the school, teachers, parents and children implies shared perceptions of the value of education as the basis of the partnership. In addition, Covey's (1989) rule of communication: "Seek first to understand, then to be understood" (p. 237) suggests the need to understand the dynamics of shared values and perceptions of education to more effectively encourage the development of partnerships with parents and sustain them over time. Fullan (1997) recognizes the value of these efforts and notes that "The research is abundantly clear: nothing motivates a child more than when 
learning is valued by schools and families/community working together in partnership...These forms of (parent) involvement do not happen by accident or even by invitation. They happen by explicit strategic intervention" (pp.42-43, as cited in DuFour \& Eaker, 1998, p. 235). Dolan, (1994), also stated that "To educate children without a deep partnership of teacher and parent is hopeless" (as cited in DuFour\&Eaker, 1998, p.235). The United States Department of Education (1995a, as cited in DuFour\&Eaker, 1998, p.235) concludes, "Thirty years of research make it clear: parents and families are pivotal to children's learning” (p.19).

In effective partnerships, each party is expected to bring specific skills and expertise to the enterprise, to offer a different perspective on issues, to provide support in difficult times, and to contribute toward the achievement of mutual goals. Effective parent-school partnerships are based on similar expectations. When parents view the school in a positive way, they are more likely to provide the necessary financial support for quality education. Dei (2004), asserts that parents who sacrifice a great deal of financial investment have certain expectations. While there may be differences of opinion from time to time, parents and educators share the same goal, the eventual success of the child (DuFour\&Eaker, 1998, pp. xix \& 238).

Hessel and Holloway (2002), posit that today's educational leader promotes the success of all students by collaborating with families and community members, responds to diverse community interests and needs, and mobilizes community resources to achieve those goals. The significance of the Interstate School Leaders Licensure Consortium Standard Four developed is the importance of administrators making informed decisions regarding collaboration with staff members and other stakeholders such as students, parents, and community leaders. Launching and sustaining collaborative relationships is underscored in the four indicators that define ISLLC Standard Four. This standard intends to dwell on relationships with the broader community to foster learning. The indicators include: (a) understanding community needs; (b) involving members of the community; (c) providing opportunities for the community and school to serve each other and; (d) understanding and valuing diversity (ISLLC, 1996). This standard and indicators affirm the importance of engaging parents and community citizens in educational processes. According to Trotman (2001), many parents are aware of the disparity between themselves and school staff and choose to stay away. The faculty and staff may also fail to involve parents with their perceived inadequate level of expertise coupled with the parents' own past negative educational experiences may further intimidate parents. Consequently, it becomes difficult to build an educational partnership. Accordingly, educators must reach out to these parents and demonstrate a visible concern for their children.

Tierney \& Auerbach (2002, as cited in Pern \& Titus, 2005) have argued, "family" involvement is likely a more appropriate focus than "parental" involvement, given changes over time in the definition of "family." Older siblings and members of the extended family may be a particularly important source of encouragement for minority students. Dei (2004), states that sometimes it helps when children have some useful examples to emulate. Older siblings who find their way through the school system also play a significant role within the family unit, as many aunts, uncles, neighbors and friends who have educational experience.

According to a study by Wilson, Cordry, Notar, and Friery, (2004) teachers concur that they cannot do it alone. For effective educational processes to occur in classrooms, parental help in partnership with educators is needed. 
The relationship between parents' involvement and children's academic learning and achievement is seen by some researchers as indirect, rather than direct (Anderson \& Keith, 1997; Reynolds \& Walberg, 1992; Shumow, Vandell, \& Kang, 1996, as cited in Gonzalez-Pienda et al., 2002). This relationship however does not diminish its positive effect on student learning.

There are many factors that constrain parental participation in schools: narrow vision of parental involvement, school personnel's negative proclivity, lack of teacher training, pressing employment issues, and cultural differences (Ramirez, 1999; Yap \& Enoki, 1995, as cited in DeCastro-Ambrosetti \& Cho, 2005). For example, in her "Western schooling and traditional society in Swaziland" Booth (1997) revealed the concern expressed by modern-day parents over their inability to instruct their children in important social behavior. They commented that when they had been young, they had spent more time at home. Furthermore, in the past, when there had been more adults living in the homestead, there had been more time for the adult leadership to instruct children in good conduct. Today, with the vast majority of young people in school...parents believed that it was part of the school's responsibility to teach respect and obedience to their children. A mother asserted, that 'If the schools are going to remove our children from us for most of the day and we will then have less time to spend with them, then they must cover this moral or social material.' Almost all parents believed that now the schools had 'taken' their children from them during the day, it was their institutional responsibility to socialize them according to Swazi tradition. The Bergers (1983, as cited in Wyness, 1995) underscored the fact that the family has now lost its primary moral functions to the education system.

Booth (1997) noticed that parents' responses revealed feelings of strong alienation from the school as an institution. She therefore, stated that if Swazi children are to succeed in school and if the national educational system as a whole is to succeed in developing an educated citizenry for all of its labor needs, a stronger bond must be fashioned between the home and school.

It is evident that, the academic success of individual students is influenced by their personal characteristics and dispositions. Equally true, however, is that as members of schools, families, and communities, students may have access to various forms of social support that can facilitate their success in school. In addition, Steinberg (1996) reports that parental involvement in the form of school visits has positive effects on student academic performance. These findings support Coleman's (1990) social theory that posits that strong relationships between schools and parents can have positive effects because they constitute a form of social capital that is of value to children's academic success (Goddard, 2003).

Common sense and the large amount of available data indicate that the family is one of the most important contexts in which a child forges his or her self, developing a system of attitudes toward various environments to relate to school and learning, enhancing motivation, interest (or lack thereof) in learning, among other things. Without family support for their children's learning, it is hard for teachers to devise academic experiences to help students learn meaningful content. Research has shown that an increase in parent involvement correlates with an increase in student achievement (Ballen \& Moles, 1994; Benjet, 1995; Center on Families, Communities, Schools, and Children's Learning, 1995a; Epstein, 1991). Trotman (2001), asserts that not only do children perform better academically and behaviorally when parents are involved, teachers' behaviors have been affected as well. Bever (1994, as cited in Trotman, 2001) found that when parents become involved, teachers normally exhibited positive attitude changes as well as improved their personal work habits. The most accurate 
predictor of a student's achievement in school is the extent to which that student's family is able to: (1) create a home environment that encourages learning; (2) communicate high, yet reasonable, expectations for their children's achievement and future careers; and (3) become involved in their children's education (DuFour\&Eaker, 1998, p. 237).

\section{METHODOLOGY}

The methods used in data collection, document review, data source and data analyses in the previous study are stated below:

\section{DATA COLLECTION}

Qualitative researchers are guided by circumstances in their decision for data collection. The purpose of the study; days in the field is normally a determined factor. In addition, the availability of participants and the availability of resources may also be considered (McMillan \& Schumacher, 2006). In the study, the researcher gained access to the premises by obtaining permission from the school administrator (Principal). The researcher had discussions with the Administrator over the telephone about the purpose of the study; the type and number of participants required, and the time frame for the study.

The data collection process began with the initial and separate visits with school administrator, as well as meetings with Teachers, Staff and the Parent-Teacher-Association (P.T.A) Chairperson. A participant's information was created to keep contact information for individuals participating in the study. This helped the researcher to schedule and confirm appointments as well as follow up sessions and facilitate maintaining a file for each study participant. Participant information forms included names, dates and locations of interview as well as demographic information, informal information conversation notes, interview notes, and interview transcripts. In addition, the researcher created a study log of all contacts, interviews, and all observations made during the course of the study (Seidman, 1998).

Participant interviews served as one of the primary data sources for the study. The researcher used two types of interviews that Creswell (2003) views as acceptable in conducting qualitative research studies. They include (a) Individual or one-on-one interviews, and (b) Focus group interviews. The researcher audio taped focus group and individual interviews as well as made handwritten and notes interview and data gathering processes to ensure that a complete record of data are maintained. Interviews were transcribed as soon as practicable after the interview session and placed in study files. The researcher estimated that each interview lasted for approximately one hour (1 hr.).

\section{DOCUMENT REVIEW}

It is common in case study research to use multiple methods and multiple sources of information including individual and focus group interviews, analysis of documents and on-site observations. Using a multi-method, multi-source data collection strategy assisted the researcher in understanding the phenomena under investigation as well as corroboratethrough triangulation the accuracy and thus the reliability and validity of data collected (Glesne, 1999; Merriam, 1998; Stake, 1995). The researcher reviewed school documents including: Parent contributions (financial and personal time) to support their child's education, participation in P.T.A meetings. Providing materials and supplies needed by students. The data indicated the level of parental involvement in their children's education. It also provided some insight into parent value of education. 


\section{DATA SOURCES}

The three main sources of data for the research study were observation, interview and document analysis. These sources provided large quantities of narrative data. The researcher selected a representative sample of about thirty (30) parents who served as key informants. They formed three (3) focus groups of ten (10) members each. There was one focus group composed of all the eleven (11) teachers. In addition, a focus group composed of three (3) staff was also convened. The first parent focus group interviewed took place at the beginning of the research study to provide direction and refinement of interview questions. Subsequent focus group interview were conducted throughout the study period (2007-2008). Individual interviews with community leaders provided a different perspective on parental value toward education. Analysis of pertinent documents proceeded concurrently with focus group and individual interviews and facilitated triangulation of data and added to confidence in its accuracy. Approximately 50 participants took part in focus group and individual interviews.

\section{DATA ANALYSIS}

Methods used to generate case study data employ a wide array of interview and documentation analysis techniques that help provide insight into factors associated with parental values and involvement in the education of their children in the Weija Community of Accra, Ghana. Semi-structured interviews enabled the researcher to interact with participants and collect pertinent data. Individual and focus group interviews complimented the information gathered through analysis of school documents. These data was cross-referenced with interview data facilitating the triangulation process and developing a more complete understanding of the phenomena from the perspective of those experiencing events. In this manner, data was confirmed or disconfirmed. A descriptive narrative was prepared that accurately reflected the circumstances, and interpretations of events were made with confidence.

\section{Perspective of Community Elders on Education}

The community elders interviewed in this study represented various groups in the community, including men and women, educated and illiterate individuals, members from various tribes, Christians and Moslems, and political leaders of the community.

During the interview sessions, the community elders expressed their different views about the value of education in the community, as well as impediments faced by residents that made attaining an education difficult. All elders interviewed concurred that education is important, especially in contemporary society and for the world economy. Their views are based on personal experiences and observations in the community and beyond. They held the view that in the past they did not value education, but these days the benefits of education are crystal clear to everyone.

Other community elders emphasized the fact that education was not valued in the past. One of these elders is Rukaya of the Zongo community in Weija, where a majority of the inhabitants are illiterate. She stated that "In the past, we did not have enough knowledge about education, but now we know the essence of education. So if your child is now in school, you need to help the child. The usual practice of buying ornaments and other things at the expense of our children's education should be discontinued so that the children will become prominent figures in the future. If we don't prioritize our choices in support of our children's education, our children may turn out to be like us mothers, who are now suffering for lack of education" (Personal Communication, May, 2008). 


\section{Perspectives of Parents on Education}

Parents' views on their family values emerged from discussions about what is most important for their children. All of the parents interviewed mentioned that education was very important with only a few mentioning moral values (training). Many of the parents claimed that they wanted to educate their children so that they could receive assistance from them during their old age. Others, however, said that they could not continue their own education because fee payments would place financial burden on their families. Consequently, they believed that it was important for them to support their children to attain higher levels of education so that they could enjoy future benefits. For example, Mr. Jajano said, "I couldn't attain a higher level of education, but I have resolved to send my children to school so that they could assist me in my old age. In my youthful age, I wish to work very hard to support my children's education for a better future" (Personal Communication, May, 2008). Some parents concurred with Mr. Jajano's notion that education is a great investment. They maintained that education is like a savings account that could yield dividends if it is well managed.

Parents held many different views with regard to the academic performance of their children. For the most part, they acknowledged their children were doing well at school and said that they were pleased with their children's performances. Parents of students who were not doing well in school identified the probable causes of their poor performance. In most instances, parents admitted that the lack of proper supervision of homework was the primary reason why their children were not doing well academically. For example, Mr. Mensah said, "I realized that normally my children perform poorly if I am not able to provide all of their school requirements, like books. Also, if supervision at home is lacking, the children take it for granted and they give much attention to the watching of the television, but once I provide them with the needed school materials and step up with supervision at home, they pick up in their performance" (Personal Communication, May, 2008).

Most parents agreed that proper home supervision of their children helped to improve their academic performance. Some parents however admitted that the falling standard of their children's academic performance may be attributed to their own absence from home. They said that they spent long hours on their jobs and spent only a few hours with their children at home. Many said that they often returned home late at night and acknowledged that this may have impeded the academic progress of their children. Some of the parents have also observed that their children performed badly in school when they fail to provide their children with the required school materials like textbooks, exercise books, and other required materials. Ms. Ode said, "Sometimes my child does well, and at certain times he falls short a lot, and when I asked him about that, he told me that it is because I did not provide all the books needed for his class work. After I fixed that problem, he picked up again" (Personal Communication, May, 2008). Some parents claimed that their frequent visits to the school helped their children to perform better in their academic work. Others also claimed that when they made sure that their children took their homework seriously, they saw improvement in their children's academic work.

However, some of the parents attributed their children's poor academic work to the poor conditions at home. They claimed that they did not have adequate space in their homes that would enable them provide a conducive learning environment for their children. They claimed that such situations impeded the progress of their children's academic performance. Some of the parents said that they did not have light in their homes and children in such homes find it difficult to do their homework. Some parents also said that being a single parent affected the 
academic performance of their children. Mr. Edem said, "I am now a single parent and what is affecting the performance of my children could be attributed to the lack of a mother at home. I believe that mothers do have a great influence on their children's education. The mother's presence provides them with some sort of peace to study, and because there is no mother, they are lacking in some aspect. So that is affecting their studies. I am praying to secure a lady who could help the children at home" (Personal Communication, May, 2008).

\section{Perspectives of Teachers on Education}

Teachers' interaction with parents helped to understand the level of their support for their children's education. Teachers indicated that they played a dual role in their jobs, which involved educating both parents and their children. They said that they worked to educate parents both through interactions at school and at home regarding the importance of education in the future lives of their children. Many also said that they frequently go to the community to talk with parents about many school-related issues, including the need for their children to do their homework, to buy books, pay school fees, etc. These teachers however affirmed that the PTA meetings have brought about some improvement in the relationship between teachers and parents as they have served as a forum in which parents and teachers may openly exchange ideas about the well-being of students, as well as on other matters that impact the school and the community as a whole.

Teachers' specific experiences with parents were related to truancy, refusal to do homework, parents' failure to provide school materials, and different views held by parents and teachers regarding punishment meted out to students by teachers. By and large, teachers believed that getting parents involved in their children's education helped to clarify parental responsibilities, contributed toward improving children's academic performance and improved their behavior in class. In addition, they noted that they saw positive changes in the behavior of parents as well.

\section{Perspectives of School Administrators}

School administrators recognized that they played multiple roles in their job. For example, they were responsible for educating teachers, students, parents, and the community as a whole. Some of the things they did to accomplish this include writing letters to parents, inviting them to the school for conferences about their children, and sometimes going to their homes to talk with them about their children's educational progress or problems. The administrators observed that by the very nature of their work each morning when children arrive, or in the afternoon when they leave, they talk to many parents about their children. At the PTA meetings, they discussed issues affecting the children and the school with parents in a group, as well as individually. Anytime they identify problems, they followed up with visits to their homes to discuss them with the parents. They observed that some of the problems that children faced in school have roots in their homes.

\section{THE BATTLE OF TRUANCY}

Truancy is a common phenomenon in every educational institution. The causes of truancy are varied. Some may be as a result of bullies scaring children from attending school. Others may be the influence of peer pressure. Whatever may be the cause of a particular situation, truancy does not provide positive results in a child's academic achievement. In the institution under review a young boy called Tachie, lived with a mother that was alleged to be taking excessive alcohol frequently. The father, who is a Seaman by profession was also said to be at sea most of the time. Due to the condition of the family, the boy was easily influenced by his peers, who were not in school frequently or were not in school at all. The mother was not a responsible 
person as a result of being under the influence of alcohol in most cases. The father could be absent from home for a period of about three (3) months. Tachie's future looked bleak because of the irresponsible parental care. However, by the intervention of school administrators, teachers, some parents of the school he attended, community members and community leaders the boy was saved from becoming a bastard and a liability to the community or state. School administrators, teachers, parents, community members or community leaders demonstrated team work to rescue this boy in the study.

Tachie was admitted into the Hope International School in the year 2009 in the lower primary five (5). He hardly attended classes for three (3) continuous days in one week. Some fish and vegetable retailers or sellers in the community who roamed the community with their merchandize everyday while school was in session reported to his teachers and school administrators of seeing one of their students loitering around in the community. Tachie, was always exposed by the prescribed school uniform he wore. The teachers of the school and school administrators tried to help this boy out from this situation by employing cohesive methods in the form of corporal punishment but all was to no avail. His parents were not helpful as a result of the influence of excessive alcohol intake by the mother and long absence of the father from home. The school administrators tried to handle Tachie as one of their own biological children. That stabilized the boy's presence in the school for a while until he recoiled back to his old shell. Tachie, proceeded on with this awful behavior up to his final year of Junior High School. He found himself in a class which was made up of about $70 \%$ females and 30\% males. The class had two girls who were so influential that they were able to influence their colleagues to act against the rules and regulations or policies of the school. The entire class became full of stubborn students. They failed to obey instructions issued by school administrators and teachers. The regular class teachers, as well as part-time teachers could not handle these students. They refused to listen to advice or take instructions from both teachers and school administrators. Already, Tachie was infested with the spirit of truancy and finding himself in a group of final year students who were stubborn rendered him as a dangerous human species to the school, the community and state as well.

On one occasion, the school administrators and teachers decided to convene a meeting with the teachers, school administrators and parents of the students in the final year and some community leaders. This meeting was outside the usual Parent-Teacher Association (PTA) meetings. It was only a meeting with parents of the final year students. The discussion of the meeting was held behind closed doors. A decision was taken that a cross-section of the parents of the children should address the students in turns in the classroom of the final year students. There was no formal agenda, yet the outcome of the meeting was very successful. Five (5) of the parents and two (2) community leaders addressed the students in their classroom, with the support of the other parents, teachers and the school administrators. It was in the form of advice to the students to take their studies seriously and also give respect to their school authority. At the end of deliberations a challenge was thrown to the students to promise that they will take things seriously. Surprisingly, Tachie was the only student who owned up that he will do what the parents have said. He said, "I promise to take you seriously, God bless you and thank you" (Personal Communication, June 12, 2013).To the amazement of everybody Tackie, got serious with his studies, he was punctual to school and very cooperative with his teachers and school administrators. Many thought that it was a nine day wonder and also too late for him to catch up with the rest of the class since he was already in his final year and had only five (5) months to leave the school for another chapter to be opened in his life. However, Tachie proved his skeptics wrong. He was the first candidate to have received the examination results 
of the Junior High School as well as the admission letter to pursue further studies in the Senior High School. With his interest in technical education he succeeded in gaining admission into one of the renowned schools in the country that is Takoradi Secondary/Technical High School situated in the second largest sea ports in Ghana.

Tachie, is now a happy student pursuing High School education. All the credit goes to the team work of school administrators, teachers, parents, community members and community leaders. Though Tachie did not have responsible parents, the teamwork by other parents of his school, teachers, school administrators, community leaders and community members saved his education.

\section{CONCLUSION AND RECOMMENDATIONS}

The study confirmed teachers' view that they cannot do it alone, as far as the education of children is concern (Wilson et al. 2004). Therefore, educating children and for that matter the success of schools remain a collective responsibility of parents, teachers, school administrators, community leaders and community members. There is the need therefore to strengthen parent-teacher relationship in schools. This can be done by encouraging parents to serve on committees such as the school management committees, disciplinary committees, counseling committees or units and any other befitting committees. When students see parents even other than their own parents at school, they feel connected to their homes and become conscious of their behavior and develop positive perception toward schooling. That will contribute toward the performance of the student's academic work as well.

In addition, teachers and school administrators should always try to be on the same note. In a situation whereby school administrators and teachers are not united in their discharge of duties, students take advantage to misbehave, and truancy get deepen. It was obvious that the collaboration between the school administrators and the teachers saved the child playing truancy in this study.

The community leaders and members should be regarded as key partners of the school. The study depicts that the community members helped to detect the truancy of the seaman's child. The hawkers or women going round in the community with their merchandise spotted the truant boy and reported their observation to the school authorities. There is every indication that the school had good relations with the members of the community. There is therefore the need to strengthen the relationship between the school and the community. Teamwork, among parents, teachers, school administrators, community leaders, and community members is indispensable for student success in education.

The perception by certain individuals or parents that schools have come into existence to take over parents' responsibilities should be discouraged. Both parents and the school need to work together to educate the child. Parents, who are aware of the disparity between themselves and school staff and therefore choose to stay away, should be discouraged from doing so. The faculty and staff who also fail to involve parents with their perceived inadequate level of expertise should desist from doing so. Parents should not allow their own past negative educational experiences intimidate them. They should rather get involved in building educational partnership. The resilience and commitment of parents, teachers, school administrators, community leaders and community members contributed toward the salvation of Tachie from losing his education. This phenomenon re-echoed the popular saying to be each other's keeper. In addition, it revitalizes the idea of educating children to be the responsibility of the entire community and not limited to only the biological parents of the child or school. 


\section{References}

Arlington Heights School District 25 (1999). District policies and procedures. Retrieved April 6, 2007, from http://www.ahsd25.k12.il.us/Policies/community.html

Astone, N. M., \& McLanahan, S. S. (1991). Family structure, parental practices and high school completion. American Sociological Review, 56(3), 309-320.

Ballen, J., \& Moles, O. (1994). Strong families; strong schools: Building community partnerships for learning. Washington, DC: U.S. Department of Education.

Benjet, C. (1995). The impact of parent involvement on children's school competence: The interaction between quantity and quality of involvement. Paper presented at the biennial meeting of the Society for Research in Child Development, Indianapolis, Indiana.

Boal, C. A., (2004). A three-way partnership with families. Principal (Resto, Va.), 83 (3), 26-28.

Booth, M. Z. (1997). Western schooling and traditional society in Swaziland.

Comparative Education, 33 (3), 433-451.

Center on Families, Communities, Schools, and Children's Learning (1995). Parent perspectives and beliefs about school-to-home communication affects their involvement in their children's learning. Baltimore: John's Hopkins University.

Charlton, C. A. (1983). A study of Colorado's 4-day school week program as it relates to utilization of school facilities. ED 230-337. Retrieved April 6, 2007, from

http://www.ericdigests.org/pre-92l/small.htm

Coleman, J. S. (1990, 1994). Foundations of social theory. Cambridge, MA: Harvard University Press.

Covey, S.R. (1989). The 7 habits of highly effective people: Powerful lessons in personal change. New York: Simon and Schuster.

Creswell, J.W. (2003). Research design: Qualitative, quantitative, and mixed methods approaches (2nd ed.). Thousand Oaks, CA: Sage Publications.

Cunningham, C. (2004). Engaging the community to support student success. Teacher Librarian, 31 (4), $33-36$.

DeCastro-Ambrosetti, D., \& Cho, G. (2005). Do parents value education? Teachers' perceptions of minority parents. Multicultural Education, 13 (2), 44-46.

Dei, G. J. S. (2004). Schooling and education in Africa: The case of Ghana. Trenton: Africa World Press, Inc.

Dufour, R., \& Eaker, R. (1998). Professional learning communities at work: Best practices for enhancing student achievement. Bloomington, IN: National Educational Service.

Epstein, J. (1991). Effects on student achievement of teachers' practices of parent involvement. Advances in Reading I Language Research, 5, 261-276.

Epstein, J. L., \& Salinas, K. C. (2004). Partnering with families and communities. Educational Leadership, 61 (8), 12-18.

Fullan, M. (1997). Broadening the concept of teacher leadership. In S. Caldwell (Ed.), Professional development in learning-centered schools (pp. 43-48). Oxford, OH: National Staff Development Council.

Glesne, C. (1999). Becoming qualitative researchers: an introduction, (2nd edition). New

York: Longman.

Goddard, D.R. (2003). Relational network, social trust, and norms: A social capital perspective on students' chances of academic success. Educational Evaluation \& Policy Analysis 25 (1), 59-74.

Gonzalez-Pienda, J. A. et al. (2002). A structural equation model of parental involvement, motivational and aptitudinal characteristics, and academic achievement. The Journal of Experimental Education, 70(3), $257-287$.

Hessel, K. \& Holloway, J. (2002). Framework for School Leaders: Linking the ISLLC

Standards to Practice. Princeton, NJ: Educational Testing Service.

Interstate School Leaders Licensure Consortium (1996). Standards for school leaders. 
Washington, DC: Council of Chief State School Officers.

Lazar, Althier \& Slostad (1999).How to overcome obstacles to parent-teacher partnerships. The Clearing House 72 (4), 206-210).

McLoughlin, S. W., et al. (2003). Student motivation: A home remedy. Kappa Delta Pi Record, 39(3), 122-125.

McMillan, J. H., \& Schumacher, S. (2006). Research in education: Evidence-based Inquiry (6th ed.). Boston, MA: Allyn and Bacon.

Merriam, S. B. (1998). Qualitative research and case study applications in education. San Francisco: Jossey-Bass Publishers.

Perna, L.W., \& Titus, M.A. (2005). The relationship between parental involvement as social capital and college enrollment: An examination of racial/ethnic group differences. The Journal of Higher Education (Columbus, $\mathrm{OH}$ ) 76,(5), 485-518.

Seidman, I. (1998). Interviewing as qualitative research: A guide for researchers in education and the social sciences. New York: Teachers College Press.

Stake, R. E. (1995). The art of case study research. Thousand Oaks, CA: Sage.

Steinberg, L. (1996). Beyond the classroom: Why school reform has failed and what parents need to do. New York: Simon and Schuster.

Trotman, M. F. (2001). Involving the African American parent: Recommendations to increase the level of parent involvement within African American families. The Journal of Negro Education, 70(4), 275-285.

Tunseth, J., \& Nowicki, C.(2003). The promise of partnerships. Principal Leadership

(High School Ed.), 4 (4), 43-46.

Wilson, J., Cordry, S., Notar, C., \& Friery, K. (2004). Teacher truths: Speaking from the heart of educators. College Student Journal, 38(2), 163 - 170.

Wyness, M. G. (1995). Schooling, welfare and the policing of parents. British Journal of Sociology of Education, 16 (3), pp. 373-387. 